\title{
PROSECUTING ATTORNEYS FOR MONEY LAUNDERING: A NEW AND QUESTIONABLE WEAPON IN THE WAR ON CRIME
}

I

INTRODUCTION

Efforts to combat vice-type crimes are increasing and taking new shapes. ${ }^{1}$ In 1986, drugs, gambling, and other types of vice crimes generated an estimated $\$ 150$ billion in illegally derived revenue. ${ }^{2}$ This money is the financial base and lifeblood of the drug trafficking and organized crime industry. ${ }^{3}$ Recently, Congress concluded that by restricting the availability of this money, the profit motive behind trafficking and organized crime would dwindle and fewer drugs would be imported and sold. ${ }^{4}$ Thus, Congress decided to aim at the profit motive in attacking crime. Congress chose to

Copyright (C) 1988 by Law and Contemporary Problems

1. To economically hinder organized crime and strip criminals of their illegally derived property, Congress passed forfeiture penalties as part -of the Racketeer Influenced and Corrupt Organizations Act (RICO), 18 U.S.C. $\$ \S 1961-1968$ (West 1984 \& Supp. 1986) (originally enacted as Title IX of the Organized Crime Control Act of 1970, Pub. L. No. 91-452, § 901(a), 84 Stat. 941), and the Continuing Criminal Enterprise Statute (CCE), 21 U.S.C. $\$ 848$ (West Supp.1986) (originally enacted as part of Title II of the Comprehensive Drug Abuse Prevention and Control Act of 1970, Pub. L. No. 91-513, $\$ 403,84$ Stat. 1265).

In its most recent legislative enactment, Congress has increased minimum and maximum imprisonment terms and fines for numerous drug violations, strengthened deportation procedures, increased appopriations, and enacted a multitude of other provisions. These provisions are aimed at strengthening "Federal efforts [in] encourag[ing] foreign cooperation in eradicating illicit drug crops and in halting international drug traffic, improv[ing] the enforcement of Federal drug laws and enhanc[ing] interdiction of illicit drug shipments, [and] provid[ing] strong Federal leadership in establishing effective drug abuse prevention and education programs . . . " Anti-Drug Abuse Act of 1986, Pub. L. No. 99-570, \& 1, 100 Stat. 3207 (preamble).

2. S. ReP. No. 433, 99th Cong., 2d Sess. 2 (1986) (by the Committee on the Judiciary) [hereinafter S. REP. 433]. The Treasury Department has estimated that Americans spend $\$ 80$ million annually to buy illegal drugs. Money Laundering Legislation: Hearing on S.5572, S.1335, and S.1385 Before the Senate Comm. on the Judiciary, 99th Cong., l st Sess. 53 (1985) (statement of Stephen S. Trott, Assistant Attorney General, Dept. of Justice) [hereinafter Senate Judiciary Hearing].

3. S. ReP. 433, supra note 2, at 4 .

4. Id. However, a simple economic analysis would suggest that as supply tightens, prices increase, thus rebalancing the profit motive. See, e.g., P. Samuelson \& W. Nordhaus, Economics 5974 (12th ed. 1985); R. Lipsey, P. Steiner \& D. Purvis, Economics 61-80 (7th ed. 1984). 
achieve this goal by enacting the Money Laundering Act of 1986 which makes money laundering a federal crime with substantial penalties. ${ }^{5}$

Congress reasoned that by making it harder to launder money, the "drug traffickers would literally drown in [their own] cash" because their money would be worthless. ${ }^{6}$ The criminal and his organization would not be able to convert their "dirty" money into a manageable and "clean" form which could then be used in legitimate society. ${ }^{7}$ Congress also passed criminal and civil forfeiture provisions which specifically designate that all profits derived from money laundering schemes are subject to seizure. ${ }^{8}$

5. Money Laundering Control Act of 1986, Pub. L. No. 99-570, $\S 1351-1367,100$ Stat. 3207, 3218 (enacted as Title I.H. of the Anti-Drug Abuse Act of 1986) (to be codified at 18 U.S.C. $\$ \$ 981$ 982, 1956-1957) [hereinafter cited to the Act's future codified sections].

The new money laundering provisions are divided into two sections. Section 1956 provides:

(a)(1) Whoever, knowing that the property involved in a financial transaction represents the proceeds of some form of unlawful activity, conducts or attempts to conduct such a financial transaction which in fact involves the proceeds of special unlawful activity-

(A) with the intent to promote the carrying on of specified unlawful activity; or

(B) knowing that the transaction is designed in whole or in part-

(i) to conceal or disguise the nature, the location, the source, the ownership, or the control of the proceeds of specified unlawful activity; or

(ii) to avoid a transaction reporting requirement under State or Federal law, shall be sentenced to a fine of not more than $\$ 500,000$ or twice the value of the property involved in the transaction, whichever is greater, or imprisonment for not more than twenty years, or both.

18 U.S.C. $\$ 1956$ (a)(1). Further, the Act provides civil penalties for violations of $\S 1956(a)(1)$, in the amount of "not more than the greater of (1) the value of the property, funds, or monetary instrument involved in the transaction, or (2) $\$ 10,000$." 18 U.S.C. $\$ 1956(\mathrm{~b})$.

Section 1957 provides:

(a) Whoever ... knowingly engages or attempts to engage in a monetary transaction in criminally derived property that is of a value greater than $\$ 10,000$ and is derived from specified unlawful activity, shall be punished as provided in subsection (b).

(b)(1) ... punishment for an offense under this section is a fine under title 18, United States Code, or imprisionment for not more than ten years or both.

(2) The court may impose an alternate fine to that imposable under paragraph (1) of not more than twice the amount of the criminally derived property involved in the transaction.

(c) ... the Government is not required to prove the defendant knew that the offense from which the criminally derived property was derived was specified unlawful activity.

18 U.S.C. $\$ 1957$.

6. H.R. REP. No. 855, 99th Cong., 2d Sess., 13 (1986) (by the Committee on the Judiciary) [hereinafter H.R. REP. 855].

7. In introducting legislation to deter money laundering, Ranking Minority Member of the Senate Committee on the Judiciary, Senator Joseph Biden stated:

Money laundering is a crucial financial underpinning of organized crime and narcotics trafficking. . . Drug traffickers need money laundering to conceal the billions of dollars in cash generated annually in drug sales and to convert this cash into manageable form. . . Money laundering is part of the "life support system" of organized crime.

132 Cong. ReC. S9627 (daily ed. July 24, 1986).

8. 18 U.S.C. $\$ 981$ (a)(1). Further, 18 U.S.C. $\$ 982$ (b) applies the CCE forfeiture provisions, 21 U.S.C. $\S 853(\mathrm{c})$, (e)-(o) (1982), to violations under the new money laundering provisions of 18 U.S.C. $\$ \S 1956-1957$.

The constitutionality of subjecting attorneys' fees to the forfeiture provisions of RICO and CCE has recently gained widespread attention. Although the constitutionality of subjecting attorneys' fees to the forfeiture provisions in the new Money Laundering Control Act may be subject to question, this note will not analyze this issue.

For articles analyzing the constitutionality of the forfeiture provisions as applied to attorneys' fees, see Brickey, Forfeiture of Attorneys' Fees. The Impact of RICO and CCE Forfeitures on the Right to Counsel, 72 VA. L. Rev. 493 (1986) (concluding that the forfeiture provisisons reach attorneys' fees, 
In passing this legislation, Congress hoped to provide a strong enforcement mechanism to deter the growth of money laundering. ${ }^{9}$ However, if Congress intended to subject attorneys who accept bona fide criminal representation fees with the knowledge that the money comes from an illegal enterprise, to the new criminal penalties, then the constitutionality of the legislation is highly questionable. This note argues that if attorneys are subject to the provisions of the Money Laundering Act, then their clients' sixth amendment rights will be infringed. ${ }^{10}$ Although Congress discussed this constitutional objection, the legislative history indicates a failure to resolve the issue and the money laundering provisions are themselves silent on the matter. ${ }^{11}$ Thus, statutory and constitutional interpretation are necessary to determine whether Congress intended the money laundering provisions to cover attorneys who accept bona fide representation fees. ${ }^{12}$

The current debate is highlighted in the congressional testimony of representatives of the Justice Department and the National Association of Criminal Defense Lawyers ("NACDL"). The Justice Department argues that Congress intended to subject attorneys to the new money laundering provisions. ${ }^{13}$ Its official position is that the crime of money laundering is committed by anyone, including attorneys, who accepts money knowing that it

sixth amendment objections are overstated, and sixth amendment issues should be deferred until the conclusion of the defendant's trial); Note, Against Forfeiture of Attorneys' Fees under RICO: Protecting the Constitutional Rights of Criminal Defendants, 61 N.Y.U. L. Rev. 124 (1986) (concluding that forfeiture interferes with defendant's right to a fair trial and that RICO must be read to exclude attorneys' fees from forfeiture); Note, Forfeiture of Attorneys' Fees Under RICO and CCE, 54 Fordham L. REv. 1171 (1986) (proposing a statutory modification to provide constitutionally sufficient safeguards for defendant's rights); Note, Attorney Fee Forfeiture, 86 Colum. L. REv. 1021 (1986) (concluding that the fee-forfeiture statute is unconstitutional as applied to attorneys' fees).

For the official Justice Department analysis, see Justice Department Guidelines on Forfeiture of Attorneys' Fees, U.S. Attorney's Manual 9-111.000 (1985), reprinted in 38 CRIM. L. REP. (BNA) 300108 (Oct. 2, 1985) [hereinafter Justice Dept. Guidelines].

Although most lower courts have held that attorneys' fees are not subject to the forfeiture provisions, United States v. Estevez, 645 F. Supp. 869, 872 (E.D. Wis. 1986); United States v. Ianniello, 644 F. Supp. 452, 455-56 (S.D.N.Y. 1985); United States v. Reckmeyer, 631 F. Supp. 1191 , 1195 (E.D.Va. 1986); United States v. Badalamenti, 614 F. Supp. 194, 195 (S.D.N.Y 1985); United States v. Rogers, 602 F. Supp. 1332, 1348 (D. Colo. 1985), this position is not universal. See, e.g., Payden v. United States, 605 F. Supp. 839, 849 n.14 (S.D.N.Y.), rev'd on other grounds, 767 F.2d 26 (2d Cir. 1985). Further, the Supreme Court has not heard the issue and Congress has not given any clarification of its current ambiguous legislative intent.

9. S. REP. 433, supra note 2, at 1 . The Senate considers the growth of money laundering directly proportional to the "spread of profitable illegal enterprises." Id. at 2.

10. See infra part III.

11. 18 U.S.C. $\S \S 1956-1957$.

12. 2 A. Sutherland, Constitutional Construction $\$ 48.01$ (4th ed. 1984).

13. Senate Judiciary Hearing, supra note 2, at 71 (statement of Trott). Even though Congress was silent on the issue, the Justice Department also takes an analogous position with regard to whether attorneys' fees are subject to forfeiture under RICO and CCE. Justice Dept. Guidelines, supra note 8 , at 3001.03 .

In a recent address, former Attorney General Meese confirmed that the money laundering provisions could be used to prosecute criminal defense attorneys who accept bona fide fees which are the proceeds of criminal activity. Address by Attorney General Edwin Meese, III to the ABA Section of Criminal Justice (1987), reprinted in A Dialogue with the Attorney General, Crim. Just., Fall 1987, at 7, 8. Meese did state, however, that the Department of Justice was discussing the practical, legal, and ethical issues with representatives of the ABA and NACDC and developing guidelines which would control the actual handling of a case. Id. at 8 . 
is the proceeds of criminal activity. ${ }^{14}$ Further, the Justice Department asserts that subjecting a defendant's attorney to the money laundering provisions does not violate or infringe the defendant's sixth amendment rights. According to the Justice Department, a defendant whose only assets are tainted and is therefore unable to retain private counsel should not be treated differently from other indigent defendants. ${ }^{15}$ In contrast, opponents to the official Justice Department interpretation argue that Congress never intended attorneys who take bona fide representation fees to be subject to the statute, and that to make them so would violate their clients' sixth amendment right to counsel and undermine the present adversary system. ${ }^{16}$

This note focuses on the question of whether defendants' sixth amendment rights are violated when their attorneys are subject to criminal and civil prosecution for accepting legal fees which the attorneys know come from illegal enterprises. ${ }^{17}$ This note begins in part II by examining the provisions and legislative history of the new Money Laundering Control Act to determine whether Congress intended the criminal and civil provisions to cover attorneys who accept bona fide fees. After part II demonstrates that the history of the Act is ambiguous and congressional intent cannot be determined, part III argues that subjecting attorneys to criminal and civil prosecution violates their clients' right to counsel, right to counsel of choice, and right to effective assistance of counsel. Finally, part IV of this note concludes that a court may uphold the statute only by exempting from its provisions attorneys who accept bona fide representation fees.

II

\section{The Money Laundering Control Act}

\section{A. Criminal and Civil Provisions}

Prior to the passage of the Money Laundering Control Act, money laundering was not a federal crime as such. ${ }^{18}$ However, the Department of Justice had previously used a number of scattered federal statutes to secure criminal convictions in money laundering cases, ${ }^{19}$ and such convictions had

14. Senate Judiciary Hearing, supra note 2, at 71 .

15. Id. See also Justice Dept. Guidelines, supra note 8 , at 3003 n.7.

16. Senate Judiciary Hearing, supra note 2, at 123, 134-37 (statement of Neal R. Sonnett, National Association of Criminal Defense Lawyers). For a full discussion. of Mr. Sonnett's position, see infra note 48 .

17. Helping the client "wash" his money is widely accepted as a violation of the money laundering provisions. An attorney should not rise above the law as an exempted party in these situations. H.R. REP. 855, supra note 6, at 14-15. For example, an attorney who deposits funds, aids in the sale of property, or creates a dummy corporation for the exchange of stock as part of a scheme to conceal the proceedings of a crime is subject to prosecution. Id., at 15. See also United States v. Richter, 610 F. Supp. 480 (N.D. Ill. 1985) (upholding an indictment charging attorney with laundering money for his client), aff'd sub nom. United States v. Mangovski, 785 F.2d 312 (7th Cir. 1986).

18. Senate Judiciary Hearing, supra note 2, at 129 (statement of Neal Sonnett).

19. Id. Criminal convictions for money laundering have been secured through scattered statutes under Titles 12, 18, 21, 26, and 31 of the U.S. Code. Most convictions are obtained under various narcotics statutes, The Bank Secrecy Act, The Internal Revenue Code, The Comprehensive Drug 
been upheld on appeal. ${ }^{20}$ The new money laundering provisions are intended to consolidate prosecutions under one statute, increase the number of prosecutions, deter criminal activity which relies on money laundering, and provide a strong and effective weapon against the criminal element. ${ }^{21}$

The Money Laundering Control Act contains two provisions, section 1956 and section 1957, that define the crime of money laundering. On its face, section 1956 of the Act applies to "whoever . . conducts or attempts to conduct ... [a] financial transaction involving the proceeds of a specified unlawful activity." 22 To obtain a conviction under this provision, the prosecution must prove that the defendant knew $^{23}$ the property or cash involved in the transaction was derived from the proceeds of a specified crime, and either (1) the defendant intended to promote a crime or (2) the defendant knew that the transaction was designed to conceal the nature or source of the proceeds. ${ }^{24}$ A defendant convicted under section 1956 may receive up to twenty years in prison and substantial criminal fines. ${ }^{25}$ Civil penalties are limited to $\$ 10,000$ or the value of the property involved in the transaction. ${ }^{26}$

For a conviction under section 1957 , the prosecution must prove that the defendant (1) engaged in a monetary transaction of over $\$ 10,000,27$ (2) knew $^{28}$ the transaction involved criminally derived property, ${ }^{29}$ and (3) the property was actually derived from a "specified unlawful activity."30 Penalties

Abuse Prevention and Control Act, and RICO. Drug Money Laundering: Hearings on S.571 Before the Senate Comm. on Banking, Housing, and Urban Affairs, 99th Cong., lst Sess. 8, 23 (1985) (statement of John M. Walker, Jr., Assistant Secretary of the Treasury for Enforcement and Operations).

20. United States v. Lignarolo, 770 F.2d 971, 978 nn.9-10 (11th Cir. 1985) (affirming convictions under the Travel Act, 18 U.S.C. $\$ 1952$ (a)(1) (1982), for laundering the cash receipts of drug traffickers and noting that conduct also violated 21 U.S.C. $\$ 846(1982)$, as conspiracies to aid and abet the distribution of controlled substances); United States v. Orozco-Prada, 732 F.2d 1076 (2d Cir.), cert. denied, 469 U.S. 845 (1984) (affirming convictions under Comprehensive Drug Abuse Prevention and Control Act of 1970, 21 U.S.C. $\$ 841$ (1982), for providing money laundering services to drug traffickers).

21. Senate Judiciary Hearing, supra note 2, at 129 (statement of Neal Sonnett).

22. 18 U.S.C. $\$ 1956(a)(1)$. See supra note 5 for the full text of section (a)(1). A financial transaction is defined as any movement of funds which affects interstate commerce. 18 U.S.C. $\S 1956(\mathrm{c})(4)$.

23. 18 U.S.C. $\$ 1956(a)(1)$. Included within the scienter requirement of knowledge are instances of "willful blindness" as defined in United States v. Jewel, 532 F.2d 697, 700 (9th Cir), cert. denied, 426 U.S. 951 (1976). S. ReP. 433, supra note 2, at 9-10.

24. 18 U.S.C. $\S 1956(a)(1)$.

25. 18 U.S.C. $\$ 1956$ (a)(1). Criminal fines are limited to the greater of $\$ 500,000$ or twice the value of the property involved in the transaction.

26. 18 U.S.C. $\$ 1956$ (c).

27. 18 U.S.C. $\$ 1957$ (a).

28. Id. See supra note 23 .

29. 18 U.S.C. $\$ 1957$ (a), (c). The government is only required to prove that the defendant knew the property or cash involved in the transaction was the proceeds of any type of criminal activity. 18 U.S.C. $\$ 1957$ (c). It is unnecessary to prove that the defendant knew the property came from its specific and true source, a "specified unlawful activity" as defined in 18 U.S.C. $\$ 1956$ (c)(7). 18 U.S.C. \$1957(c); S. REP. 433, supra note 2, at 11 . For further discussion of what constitutes a "specified unlawful activity," see infra note 32 and accompanying text.

30. 18 U.S.C. \& 1957 (a). 
include imprisonment of up to ten years and fines of up to $\$ 250,000$ or twice the amount of the property involved in the transaction. ${ }^{31}$

An examination of the Act's two provisions reveals that the Act was intended to be broad in its sweep. For example, the Act applies to "whoever" and defines a "specified unlawful activity" by providing an extensive list of activities, including any predicate offense under RICO, an offense against a foreign nation involving controlled substances, any act constituting a criminal enterprise under the Controlled Substances Act, and numerous others. ${ }^{32}$

If the money laundering provisions are applied to an attorney because he accepted a representation fee from a client whose money was derived from a specified unlawful activity, the attorney could be convicted of money laundering under section 1956 upon proof that (1) he knew the money was from an unlawful activity, and (2) he knew that the defendant was using the attorney to conceal (by defending the client from a criminal prosecution) the unlawful activity. ${ }^{33}$ However, a valid defense to a section 1956 prosecution is that the acceptance of fees for legal services does not place the attorney within the statutory provisions because he did not intend to promote a criminal activity or know that the payment was designed to conceal the proceeds of a crime. Generally, an attorney is hired as an agent to represent the defendant in a criminal prosecution, not to aid and abet a conspiracy to cover up a crime. ${ }^{34}$ Congress intended section 1956 to apply only to situations where an attorney or anyone else is "washing" a criminal's money. ${ }^{35}$

Section 1957, on the other hand, seems on its face to apply to attorneys who accept representation fees, and is therefore the central focus of this note's analysis. ${ }^{36}$ Attorneys may successfully defend a section 1957 money laundering prosecution on three grounds. The first defense is that Congress

31. 18 U.S.C. $\$ 1957(b)(1)-(2)$. Subsection (b)(1) imposes "a fine under title 18." This reference is to (1) 18 U.S.C. $\$ 3623$ (a)(3), which provides the maximum fines, and to (2) 18 U.S.C. $\S 3622(\mathrm{a})$, which provides a list of factors for judicial consideration in the determination of whether to impose a fine and at what amount it should be set.

The statute also includes a jurisdictional provision which provides that the transaction (1) must occur within the United States or in the special maritime and territorial jurisdiction of the United States or (2) may occur outside of the United States if the defendant is a United States citizen. 18 U.S.C. $\$ 1957(d)(1)-(2)$.

32. 18 U.S.C. $\$ 1956(\mathrm{c})(7)(A)$-(D) (subsection (D) lists an additional twenty-four predicate offenses). Hereinafter the phrases "specified unlawful activity" and "specified criminal activity" will refer to one of the designated predicate acts under subsection (c)(7).

33. 18 U.S.C. $\$ \S 1956(a)(1)$, (c).

34. See, e.g., National Sav. Bank v. Ward, 100 U.S. 195, 198 (1880); 7A C.J.S. Attorney E' Client $\S 180(1980)$.

35. See supra note 17.

36. For section 1957's provisions, see supra note 5. See also H.R. REP. 855, supra note 6, at 14-15 (committee assumes that acceptance of bona fide representation fees would subject an attorney to the money laundering provisions under section 1956, but questions the section's constitutionality). For a complete analysis of the legislative history, see infra part II.2.

If one was to assume the government could overcome section 1956's application problems, the analysis of the provision's effect on the defendant's constitutional guarantees would be parallel to that of section 1957's analysis. See infra part III. In addition, logic suggests that prosecutors would prefer to prosecute an attorney under section 1957's provisions because the government's case would be easier to prove. See infra notes 99-103 and accompanying text. However, section 1956 does provide for substantially higher penalties (compare 18 U.S.C. $\S 1956(a)(1)$ with $\S 1957$ (b)) and a civil 
did not intend the money laundering provisions to reach attorneys who accept fees in exchange for bona fide legal services. ${ }^{37}$ A second defense is that the attorney did not "know" the payment was from the proceeds of a criminal activity. This position would be extremely difficult position to prove, because attorneys are informed of the charges against their clients and any assets which the government seeks to claim through forfeiture proceedings. ${ }^{38}$ An alternative and a safeguard against prosecution is for the attorney to demand payment from sources that are "clean," and thus not derived from criminal activity, if they exist. In many cases, however, this demand may not be practical. ${ }^{39}$ Finally, an attorney can argue that the money laundering provisions are unconstitutional as applied to his acceptance of bona fide representation fees because the effect of the provisions violates his client's sixth amendment rights. ${ }^{40}$

In summary, the money laundering provisions of section 1957 are broad enough to threaten severe penalties against attorneys who accept representation fees. Further, an attorney's only tenable defenses to a money laundering prosecution are that Congress intended to exempt attorneys who accept bona fide representation fees, and that the statute is unconstitutional as applied to him because it infringes on his client's sixth amendment rights.

\section{B. Legislative History}

The Money Laundering Control Act makes no exceptions in defining the class of persons subjected to its provisions. The Act uses the word

penalty which is subject to a "preponderance of the evidence" standard of proof. S. REP. 433, supra note 2, at 12 (test for 18 U.S.C. \& 1956(b)).

37. See infra notes 41-57 and accompanying text. The defense is that Congress did not intend the statute to extend to attorneys in this situation because the application of the provisions would violate current and prospective clients' sixth amendment rights. Raising this defense might be met with resistance under the prudential doctorine of jus tertii. However, under Craig v. Boren, 429 U.S. 190 (1976), and Carey v. Population Serv. Int'l, 431 U.S. 678 (1977), the attorney should be able to raise the third party's constitutional challenge because in this situation the third party's rights are closely tied up with the attorney's rights.

38. See supra note 23. Congress intended to include willful blindness under the scienter standard, thus foreclosing the possibility of accepting money for representation without inquiring into the charges against the defendant or inquiring into his background. Id. This analysis is very similar to the court's analysis in United States v. Ianniello, 644 F. Supp. 452, 456 (S.D.N.Y. 1985), which involved the constitutionality of applying RICO and CCE forfeiture provisions to fees paid to the defendant's attorney. The court stated:

A defendant's criminal defense counsel, who obviously has read the indictment and discussed the charges with his client, could not convincingly argue, if his client were convicted, that he lacked notice that the money received in payment of his legal fees may have come from the proscribed racketeering activity. . . Counsel, aware that conviction of his client could result in the forfeiture of his fee, would be reluctant to handle such a case. Thus a defendant ... would be denied the opportunity to obtain counsel.

Id. at 456.

Further, FED. R. CRIM. P. 7(c)(2) states: "When an offense charged may result in criminal forfeiture, the indictment . . shall allege the extent of the interest or property subject to forfeiture."

39. See, Note, Attorney Fee Forfeiture, supra note 8, at 1025 n.37 (noting that some clients will not have "untainted assets").

40. See infra part III. For discussion of the possible jus tertii objection, see supra note 37. 
"whoever."41 However, if this statute applies to attorneys who accept representation fees which are from illegal activities, their clients' sixth amendment rights to counsel may be violated. ${ }^{42}$ Thus, it is appropriate to examine the legislative history to look for congressional intent in favor of an interpretation which will reconcile the statute's provisions and the Constitution's sixth amendment mandate. ${ }^{43}$

The legislative history of the Money Laundering Control Act is ambiguous as to whether Congress intended to exempt attorneys from the Act's provisions. ${ }^{44}$ The original bill submitted to the House of Representatives from the Committee on the Judiciary expressly limited the Act by stating that the paragraph [making it a crime to engage knowingly in a financial transaction involving criminally derived property under section 1957] "does not apply to financial transactions involving the bona fide fees an attorney accepts for representing a client in a criminal investigaion or any proceeding arising therefrom." 45 This provision was adopted because the Judiciary Committee was

very concerned [that without the provision] the potential for ... [full] discovery might have had the effect of inhibiting the attorney's complete investigations of the client's case (to avoid learning any information which could have triggered this offense) and would thus have interfered with the client's sixth amendment right to effective assistance of counsel. ${ }^{46}$

The House Committee, however, concluded that attorneys are not a special class of citizens and that they should be subject to the money laundering provisions if they aided in a "scheme to conceal the proceeds of a crime." 47

41. 18 U.S.C. §§ 1956(a)(1), (b), 1957(a).

42. See infra part III.

43. Courts must, if possible, construe a statute to be constitutional if the legislative history can be interpreted to show a congressional intent which is reconcilable with constitutional mandates. 2 A. SUtherLand, supra note $12, \S 56.04$. Since the money laundering provisions may infringe on fundamental freedoms contained in the sixth amendment, see infra part III, the statute will be strictly construed to eliminate any unconstitutional applications which were not expressly included within the statute's provisions. Id. $\$ \S 58.02,58.04$. If the court cannot find an interpretation which reconciles legislative intent with constitutional mandates, it must strike down the law. United States v. Clark, 445 U.S. 23, 27 (1980); 2 A. SutherLand, supra $\$ 56.04$.

44. See infra notes 45-57 and accompanying text.

45. H.R. ReP. 855, supra note 6, at 1 . This paragraph was an amendment introduced on June 24, 1986 , by the bill's co-sponsors and adopted by the Subcommittee on Crime. Id. at 9 . There was no similar provision in the Senate's bill (S.2683). S. Rep. 433, supra note 2. However, the Senate considered the issue during the first session of the 99th Congress in October of 1985 during hearings of the Committees on the Judiciary. See infra notes 48-53. The House's paragraph was left out of the final version signed by the President. See infra notes 54-55 and accompanying text.

46. H.R. RE. . 855, supra note 6 , at 14. For an analysis of the claim that a client's sixth amendment right to effective assistance of counsel are violated by the money laundering provisions, see infra part III.C.

47. H.R. REP. 855, supra note 6, at 15. For an example of illegal actions which may not be taken by an attorney, see supra note 17. Further, the crime of money laundering applies to any businessman such as a stock broker, real estate agent, auto dealer, or jeweler who engages in or helps a criminal engage in a transaction which the businessman knows is part of a scheme to conceal or disguise the ownership of criminally derived property or cash. H.R. REP. 855, supra note 6 , at 15 . An illegal action can be as insignificant as selling a car or a bag of groceries to someone whom the seller knows is using "tainted" money. Id at 14-15. 
In the Senate, a great deal of discussion also focused on the effects of applying the money laundering provisions to attorneys who accepted tainted representation fees. ${ }^{48}$ This discussion occurred, however, only during the first session of the 99th Congress, and the bill approved by the Senate Committee on the Judiciary during the second session failed to include any provision for exempting attorneys who accept bona fide representation fees. ${ }^{49}$ In the second session of the 99th Congress, the only clues to the Senate's intent were the remarks made by Senator Strom Thurmond, Chairman of the Senate Committee on the Judiciary, when he introduced the legislation. ${ }^{50}$ Senator Thurmond's statements are especially significant because they were included in the final Senate report. ${ }^{51}$ Senator Thurmond stated that "most disturbing is the increasing willingness of a few dishonest attorneys, accountants, and bankers to participate in these sophisticated schemes." 52 This statement indicates that, like the House, the Senate believed the legislation would only be applied against attorneys who arranged sham transactions, ${ }^{53}$ not against those who represented defendants for bona fide fees.

Before the bill became law, ${ }^{54}$ the reconciliation committee struck a compromise that omitted the express limitations proposed by the House and included only general language making application of the statute universal. ${ }^{55}$ Although Congress never expressly limited money laundering provisions to exclude attorneys, neither did it give a rationale for the omission of the House's paragraph. It therefore seems probable that Congress either did not intend to exempt attorneys from the money laundering provisions or did intend to defer the question of whether or not to exempt attorneys to the courts upon a finding of a constitutional infringement. However, it is

48. On one side, Stephen S. Trott, an Assistant District Attorney General, expressed the view of the Justice Department that attorneys should not be treated differently from anyone else and will be subjected to the provisions in essentially the same manner as under the Department's Guidelines for forfeiture (attorney subject to statute's provisions if he accepted the fees knowing that they were the proceeds of criminal activity). Senate Judiciary Hearing, supra note 2, at 71.

In opposition, Neal R. Sonnett expressed the concern that, without an exemption, the statute would put an "end to the retained criminal bar as we know it, and [result in] the demise of our balanced adversarial system of justice." Senate Judiciary Hearing, supra note 2, at 124. Sonnett argued that threatening serious criminal prosecution against attorneys who take fees to represent criminal defendants (1) denies that client's sixth amendment right to retain counsel of his or her own choice; (2) impedes that attorney's ability to render effective assistance; (3) impairs the relationship of trust and confidence between client and counsel; (4) allows the government to manipulate the defendant's choice of counsel; (5) discourages or disallows competent attorneys from agreeing to represent clients in criminal cases; and (6) diverts counsel's efforts away from preparation of a defense by requiring the attorney to litigate issues related to the attorney-client relationship. Id. at 138-39 (prepared statement by Mr. Sonnett).

49. S. REP. 433, supra note 2.

50. 132 Cong. Rec. S9626 (daily ed. July 24, 1986) (statement of Senator Strom Thurmond).

51. See S. REP. 433, supra note 2, at 3-4.

52. Id. (emphasis added).

53. See supra note 17.

54. The deletion of the House's paragraph must have occurred in an unpublished conference between the House and Senate in October 1986.

55. See 18 U.S.C. $\$ 1957(\mathrm{a})$. 
relatively certain that Congress did not intend to subvert a defendant's constitutional rights under the sixth amendment. ${ }^{56}$

Given the statute's plain language and the underlying legislative history, a court which accepts the argument that the statute violates a defendant's sixth amendment rights will probably construe the statute to avoid an unconstitutional application and a striking down of the statute. Thus, the court would likely create an exemption for attorneys who accept bona fide representation fees which they know are tainted. ${ }^{57}$

\section{The Sixth Amendment Right to Counsel and its Applications to Defendants Whose Attorneys are Threatened WITH Prosecution}

The sixth amendment, which provides that "in all criminal prosecutions, the accused shall enjoy the right ... to have the Assistance of Counsel for his defense," 58 has been interpreted to include three distinct rights: the right to representation by counsel, ${ }^{59}$ the right to counsel of choice, ${ }^{60}$ and the right to effective assistance of counsel. ${ }^{61}$

\section{A. Right to Counsel}

The right to representation by counsel is guaranteed in all criminal prosecutions. ${ }^{62}$ However, if private criminal attorneys as a class feel threatened with criminal or civil prosecution, ${ }^{63}$ they will be highly reluctant to

56. In an analogous situation, the lower federal courts have split on the question of whether Congress intended to subject attorney fee-forfeitures under RICO and CCE provisions, see supra note 8 , in light of congressional silence in the legislative history and one congressional footnote which provided, "Nothing in this section is intended to interfere with a person's Sixth Amendment right to counsel." H.R. Rep. No. 845, 98th Cong., 2d Sess. 19, n.1 (1984). For a complete list of sources which discuss the constitutional implications of subjecting attorneys' fees to forteiture, see supra note 8.

57. See supra note 43 .

58. U.S. Const. amend. VI.

59. See, e.g., Gideon v. Wainwright, 372 U.S. 335, 344-45 (1963); Douglas v. California, 372 U.S. 352, 356-58 (1963) (right to counsel through defendant's first direct appeal); Powell v. Alabama, 287 U.S. 45, 66 (1932). See also infra part III.A.

60. See, e.g., Crooker v. California, 357 U.S. 433, 439 (1958), rev'd on other grounds, Miranda v. Arizona, 384 U.S. 436 (1966) (fourteenth amendment secures in state prosecutions the right to an opportunity to retain counsel of one's own choosing); Chandler v. Fretag, 348 U.S. 3, 10 (1954) (defendant must be given responsible opportunity to employ and consult with counsel); Powell v. Alabama, 287 U.S. 45, 66 (1932) (right to counsel includes a fair opportunity to retain counsel of choice). See also infra part III.B.

61. See McMann v. Richardson, 397 U.S. 759, 771 (1970) (expressly recognizing right); Strickland v. Washington 466 U.S. 668, 687-96 (1983) (putting forth a definite two-part test). See also infra part III.C.

62. See supra note 59. For a Supreme Court history of the right to counsel, see Berger, The Supreme Court and Defense Counsel: Old Roads, New Paths-A Dead End?, 86 Colum. L. REv. 9, $13-102$ (1986); Note, Wilson v. Mintzes: A Case of Ineffective Assistance or Denial of Counsel of Choice, 17 U. TOL. L. REV. 615, 616-22 (1986).

63. The situation presented would involve acceptance of a fee from a client who is charged with a "specified unlawful activity", which is defined in 18 U.S.C. $\$ 1956(\mathrm{c})(7)$, and whose money the attorney knows came from an illegal source. 
represent a defendant who is charged with criminal activities. ${ }^{64}$ Further, an attorney's exposure is increased by the threat of state bar sanctions ${ }^{65}$ and possible vindictive prosecution by U.S. Attorneys who lose the underlying criminal case and want a scapegoat. ${ }^{66}$

The Money Laundering Control Act's chilling effect on the availability of retained counsel is a problem that the Justice Department believes can be solved by the appointment of counsel. ${ }^{67}$ However, the effectiveness of this alternative is questionable. If a client is "too hot to handle" 68 and cannot obtain private representation because all of his assets are tainted, ${ }^{69}$ the court will have to consider the defendant "financially unable to obtain adequate representation" and appoint counsel under the Criminal Justice Act. ${ }^{70}$ Some courts and critics have noted that the public defense bar lacks the resources, expertise, and time necessary to represent competently defendants charged with RICO, drug trafficking, and vice-type offenses. ${ }^{71}$

One federal district court has recently observed that mounting a RICO defense is "far beyond the resources or expertise of the average federal public defender's office" because it is already overtaxed, the issues in these cases are extremely complex, the facts and information to be marshalled are vast, and the time required for representation often lasts two or three years during grand jury investigations. ${ }^{72}$ The court concluded that "[c]ounsel appointed ninety or one hundred and twenty days before trial [under the Criminal Justise Act] is patently inadequate."73 Although the Criminal Justice Act will

64. Compounding the chilling effect of prosecution is the attorney's exposure to government seizure of his fee under the forfeiture provisions of the Money Laundering Control Act, 18 U.S.C. $\$ \$ 981-982$, RICO or CCE. See supra note 1. In general, an attorney cannot afford to handle long and complex cases without an assurance of payment. See Note, Against Forfeiture of Attorneys' Fees Under RICO, supra note 8 , at 133-34.

65. State bar sanctions can be based upon violations of the independence requirements of the Model Code of Professional Responsibility Canons 4, 5, 9 (1980). See generally 7 Am. Jur. 2d Attormeys at Law $\$$ 40, 48-55 (1980).

66. See infra part III.C.3.

67. Justice Dept. Guidelines, supra note 8, at 3002.

68. This expression designates a defendant whose assets were all derived from criminal activity and against whom the government has a solid case.

69. A serious threat of criminal prosecution against an attorney who accepts a case for a fee would probably discourage all members of the private bar, unless one takes the case in order to challenge the constitutionality of 18 U.S.C. $\$ 1956-57$, as applied to attorneys.

In United States v. Badalamenti, 614 F. Supp. 194, 196 (S.D.N.Y. 1985), the court stated that an attorney was either "foolish, ignorant, beholden or idealist" to take a case where the attorney's fee was subject to forfeiture. An analogous situation exists here, except the penalties are enhanced. See supra notes 63-66 and accompanying text.

70. Criminal Justice Act of 1964, 18 U.S.C. $\$ 3006(A)(a)(1982)$. See also Gideon v. Wainwright, 372 U.S. 335, 344 (1963) (holding that a court must appoint counsel if the defendant is unable to retain counsel); FED. R. Crv. P. 44(a) (indigent defendants have the right to appointed counsel from initial appearance through appeal).

71. See Krieger \& Van Dusen, The Lawyer, The Client and The Law, 22 AM. CRIM. L. Rev. 737,73940 (1984) (acknowledging the accomplishments and capabilities of the Public Defender's Office, but noting that they were not designed to replace the private lawyer in situations which require specialists, such as drug trafficking and RICO prosecutions); Note, Attorney Fee Forfeiture, supra note 8, at 1045 (noting the "ills afflicting" the public bar).

72. United States v. Rogers, 602 F.Supp 1332, 1349 (D. Colo. 1985).

73. Id. (emphasis added). 
force courts to appoint counsel as constitutionally required, if the public bar is unable to represent a defendant adequately, his sixth amendment right to counsel is infringed.

A second objection arises from the taxpayer. It seems grossly unfair that tax dollars should be spent to pay the legal fees of a wealthy defendant in order to protect his attorney from prosecution. The social cost of appointing free counsel to wealthy defendants includes money, time, and resources which could be used in the representation of truly indigent defendants. This cost is unjustifiably high in relation to the social cost of exempting attorneys from prosecution upon proof that fees paid were for the bona fide representation of a client. ${ }^{74}$

\section{B. Right to Counsel of Choice}

In Powell v. Alabama ${ }^{75}$ the United States Supreme Court recognized that a defendant must be "afforded" a "fair opportunity to secure counsel of his own choice." Although this right is not absolute, ${ }^{76}$ the courts have balanced the public's interest in the orderly and efficient administration of justice against the defendant's interest in obtaining a prompt and fair trial and in exercising his right to choice of counsel. ${ }^{77}$

In attorney fee forfeiture cases, ${ }^{78}$ the problems that result from attempting to seize the defendant's assets are similar to the concerns of the Powell Court. The difficulty is not that the defendant cannot afford to hire a particular attorney of his choice, but that no attorney can be retained because of the government's threat of seizure of the defendant's assets, including fees paid to or owed to his attorney. ${ }^{79}$ The money laundering provisions create a

74. An alternative solution to the apparent unfairness of forcing society to spend tax dollars to pay for a wealthy defendant's representation would be to strip the defendant of his assets, thus making him an indigent. However, this solution would violate the fifth amendment's due process clause, and the principle that one is innocent until proven guilty. U.S. ConsT., amend. V.

75. 287 U.S. 45,53 (1932). See also cases cited supra note 60

76. See, e.g., Morris v. Slappy, 461 U.S. 1, 10-15 (1983) (balancing process applied); United States v. Curicio, 680 F.2d 881, 890 (2d Cir. 1982); United States v. Poulack, 556 F.2d 83, 86 (1st Cir.), cert. denied, 434 U.S. 986 (1977).

77. See Morris v. Slappy, 461 U.S. 1, 10-15 (1983) (victim's rights considered in balancing process); Hollaway v. Arkansas, 435 U.S. 475, 486-87 (1978) (administrative concern over delay tactics); Ungar v. Sarafite, 376 U.S. 575, 588-91 (1963) (no mechanical test to apply, look at circumstances of each case). For a history of the right to counsel of choice, see Note, supra note 62 , at 630-34.

Indigents are appointed counsel by the court under the Criminal Justice Act, 18 U.S.C. § 3006(A) (1982). Most courts and commentators do not recognize a right to counsel of choice for indigents. However, substitute counsel must be appointed upon a showing of good cause. United States v. Young, 482 F.2d 993, 995 (5th Cir. 1973) (no right to pick a particular lawyer or demand substitute except for good cause); McKee v. Harris, 649 F.2d 927,931 (2d Cir. 1981); United States v. Calabro, 467 F.2d 973, 986 (2d Cir. 1972) (in order to warrant appointment of substitute counsel, defendant must show good cause, such as conflict of interest, irreconcilable differences, or complete communication breakdown). See generally Berger, supra note 62, at 49-55; Tague, An Indigent's Right to the Attorney of His Choice, 27 STAN. L. REv. 73 (1974).

78. See supra notes $63-71$ and accompanying text.

79. United States v. Badalamenti, 614 F. Supp. 194, 197 (S.D.N.Y. 1985) (the problem is that "lawyers will refuse to accept [the client's] retainer and refuse to represent him"). See supra notes 6371 and accompanying text. 
similar situation in which a defendant cannot retain an attorney because of the government's threat of criminal and civil sanctions against any attorney who takes the case for a fee. ${ }^{80}$ Tying this unavailability of counsel directly to the threat of government action leads to a balancing of the defendant's interest in his sixth amendment right to counsel of choice against the government's interest in enforcing the money laundering provisions against attorneys who take bona fide representation fees which are tainted.

Congress's purpose in passing the Money Laundering Control Act ${ }^{81}$ was to stop the "spread of profitable illegal enterprises" by depriving criminals of the methods used to disguise the illegal nature and true sources of their income. ${ }^{82}$ Subjecting attorneys to criminal prosecution for accepting tainted representation fees does not interfere with the government's interest in shutting down money laundering operations, ${ }^{83}$ because attorneys serve the purpose of providing counsel to defendants who are accused of a crime, not one of encouraging the defendant's illegal conduct. The Justice Department's approach is confusing in that it advocates attacking the basic structure of the adversarial system of justice in its attempt to stop drug trafficking and vicetype crimes.

The right to counsel of choice was designed to ensure objective fairness in the proceedings ${ }^{84}$ and is essential to maintain the integrity of the adversarial system of justice. ${ }^{85}$ The threat of criminal or civil prosecution against an attorney interferes with his client's right of free choice, ${ }^{86}$ denies him a fair opportunity to hire counsel, ${ }^{87}$ impedes the fairness of the proceedings, ${ }^{88}$ and destroys the integrity of the adversarial system of justice. ${ }^{89}$ The statute must therefore either bend to allow an exception or be ruled unconstitutional: The government's interest in subjecting attorneys to the money laundering provisions clearly does not outweigh the potential damage to the defendant's right to counsel of choice..$^{90}$

80. See supra text accompanying notes 25-26.

81. See supra note 5.

82. See supra note 77

83. It is accepted that the Department of Justice can constitutionally prosecute an attorney who is "washing" money for a client through the creation of sham transactions. See supra notes $17,47$.

To conclude that the payment of legal fees encourages money laundering ignores economic realities. Criminals and drug traffickers launder profits from illegal transactions in order to be able to spend it on obtaining property in legitimate society, not to pay attorneys for services rendered. Further, the amount spent in defending oneself by hiring an attorney, say $\$ 40,000$, is minute compared to the profits made on a $\$ 150$ billion industry. S. REP. 433 supra note 2, at 2.

84. See, e.g., Strickland v. Washington, 466 U.S. 668, 689 (1984); United States v. Morrison, 449 U.S. 361,364 (1981); Gideon v. Wainwright, 372 U.S. 335, 344 (1963).

85. Linton v. Perini, 656 F.2d 207 (6th Cir. 1981) (right to counsel of choice is necessary to maintain basic trust between client and attorney, a cornerstone of the adversarial system), cert. denied, 454 U.S. 1162 (1982).

86. See Faretta v. California, 422 U.S. 806, 834 (1974) (the defendant's free choice must be honored as it is one of the basic elements on which the law is based).

87. See supra notes 64-66 and accompanying text.

88. See supra notes $68-71$ and accompanying text; infra part III.C.

89. See infra part III.C.3.

90. A court faced with the realization that the statute is unconstitutional as applied will have the options of striking down the whole statute or holding that Congress did not intend the statute to 


\section{Right to Effective Assistance of Counsel ${ }^{91}$}

1. Conflict of Interest. The sixth amendment also embodies the right to effective assistance of counsel. ${ }^{92}$ This right is infringed when a defendant, who is charged with a specific predicate offense under the Act, ${ }^{93}$ retains an attorney whose interests are in conflict with those of his clients.

In Strickland $v$. Washington, ${ }^{94}$ the court stated that the government violates a defendant's right to effective counsel when it interferes "with the ability of counsel to make independent decisions." The defendant's right can also be infringed by his own counsel by "failing to render "adequate legal assistance." "95 In certain situations, a presumption of prejudice arises from violation of the defendant's right to effective assistance of counsel. ${ }^{96}$ The presumption arises, for example, when the defendant is actually or constructively denied assistance of counsel, when the prosecution interferes with counsel's assistance, or when counsel has an actual conflict of interest with his client. ${ }^{97}$

By subjecting attorneys to the threat of criminal and civil penalties for accepting bona fide representation fees, the government creates a conflict of interest between the attorney and client. ${ }^{98}$ This conflict arises because the

apply to the unconstitutional situation. Because courts must adopt a constitutional statutory interpretation when the legislative intent will support it, 2 A. SutherLAND, supra note $12, \S 56.04$, a court should also opt for creating an exception where the legislative history is ambiguous. See supra note 43.

91. Ineffective assistance claims are almost exclusively raised as a basis for reversal of a criminal conviction and predicated on what happened at trial. See, e.g., Strickland v. Washington, 466 U.S. 668 (1984) (defendant claimed denial of effective assistance during trial and sentencing hearing); United States v. Katz, 425 F.2d 928, 931 (2d Cir. 1970) (defendant claimed counsel was sleeping during trial). However, this note's purpose is to show that a defendant, whose criminal defense attorney accepts his case for a fee, in light of the criminal penalties under 18 U.S.C. $\S 1956$, is automatically deprived of his sixth amendment right to effective assistance of counsel because of the inherent conflicts of interest which permeate the attorney-client relationship and the adversarial process.

92. See supra note 61 .

93. See supra note 32 .

94. 466 U.S. 668,686 (1984). The court set out a two-pronged test when analyzing a claim that counsel failed to render adequate assistance. The test states:

First, the defendant must show that counsel's performance was unreasonable on the facts of the particular case. This requires that a convicted defendant identify acts or omissions of counsel that are not the result of reasonable professional judgment. Second, the defendant must show that the deficient performance prejudiced the defense. This requires showing that there is a reasonable probability that, but for counsel's unprofessional errors, the result of the proceeding would have been different.

Id. at 687 .

95. Id. at 686 (quoting Cuyler v. Sullivan, 446 U.S. 335, 344 (1980)).

96. Id. at 692. In United States v. Cronic, 466 U.S. 648, 659 nn.25, 26 (1984) (companion case to Strickland $\mathrm{v}$. Washington), the Court stated that in order to have a sixth amendment violation, the government's interference must be of the "magnitude" of counsel being "either totally absent, or prevented from assisting the accused during a critical stage of the proceedings." For an argument that the money laundering provisions constructively prevent the assistance of counsel by creating conflicts of interest which force the defendant's attorney to give erroneous advice, see infra text accompanying notes $98-105$.

97. Strickland v. Washington, 466 U.S. at 692 . Counsel breaches his duty of loyalty when burdened by an actual conflict of interest. Id. at 692 (citing Cuyler v. Sullivan, 446 U.S. at 345-50).

98. See infra notes 99-111 and accompanying text. 
attorney's criminal and civil liability is determined, in part, by the outcome of the defendant's trial.

In money laundering prosecutions against an attorney whose client has been convicted, the prosecution's burden is limited to proving that the money was derived from a statutorily designated illegal source and that counsel knew of this fact. ${ }^{99}$ In most section 1957 cases this burden is reduced because the prosecution usually goes after the defendant's assets in a simultaneous forfeiture action under RICO or CCE. ${ }^{100}$ In these circumstances, the jury is instructed to render a special verdict determining which assets were criminally derived and must be forfeited. Thus, if the attorney accepted any of these forfeited assets as payment, the first part of the prosecution's case is complete.

Successful prosecution of attorneys is made easier by the lack of a defense to knowledge of the illegal origin of the clients' fees. Counsel is made aware of the indictments against the defendant prior to accepting representation fees and could have required the client to verify the source of the funds. ${ }^{101}$ Failure to inquire would not constitute a valid defense because the attorney's actions would constitute willful blindness. ${ }^{102}$ In effect, if the client is found guilty, the prosecution will have little difficulty in convicting the client's attorney. ${ }^{103}$

Because the attorney's liability under section 1957 is based, in part, on the outcome of his client's case, the attorney's representation will be skewed in favor of protecting his own self-interest instead of the best interests of his client. An attorney may negotiate a plea or change trial tactics which benefit counsel at the client's expense. For example, in return for a guilty plea, or similar concession, the attorney may bargain for the inclusion of a stipulation that assets transferred to the attorney were not the proceeds of criminal activity specified in the statute. ${ }^{104}$ Alternatively, if no deals are made concerning the attorney's fee, counsel may advise his client to go to trial with an innocent plea rather than a guilty plea, even though a guilty plea may better serve the client's interest. ${ }^{105}$

\footnotetext{
99. 18 U.S.C. $\$ 1957(a)$.

100. See supra note 1 .

101. See supra text accompanying note 38 .
}

102. S. REP. 433, supra note 2, at 10 (as defined in United States v. Jewel, 532 F.2d 697, 700 (9th Cir.), cert. denied, 426 U.S. 951 (1976)).

103. For two cases which discuss this situation and the resulting effects on the client's sixth amendment right to effective assistance of counsel, see infra text accompanying notes 106-10.

104. In cases which include the possibility of attorney fee forfeiture, the Department of Justice Guidelines, supra note 8 , at 3008 , authorize agreements which exempt from forfeiture an asset transferred to an attorney for legal fees. The Guidelines also state that it is inappropriate to give notice that a fee may be forfeitable for the purpose of harassing attorneys or for the purpose of "targeting certain attorneys and attempting to prevent them from representing criminal defendants in certain cases." Id. at 3006. Furthermore, the Wall Street Journal reports that "[a]n internal Justice Dept. memorandum has cautioned restraint [in using the money laundering provisions against defense lawyers], and orders that any indictment against lawyers involving fees be cleared first in Washington." Allen, Defense Lawyers Fear Becoming Targets Under Sweeping Money Laundering Law, Wall St. J., Dec. 2, 1986, at 35, col. 4.

105. For a similar analysis of this type of conflict of interest in cases which involve the forfeiture of attorney fees, see United States v. Ianniello, 644 F. Supp. 452, 457 (S.D.N.Y. 1985) (such action 
Recently, the Second and Third Circuits have held that an actual conflict of interest arose in situations similar to the one presently discussed. In Government of Virgin Islands v. Zepp, ${ }^{106}$ the court held that the defendant's sixth amendment right to effective assistance of counsel was violated because his attorney was potentially liable for aiding and abetting or encouraging the defendant's illegal conduct. The court reasoned that "it is unrealistic" to assume that the defendant's "attorney vigorously pursued his client's best interest entirely free from the influence of his concern to avoid his own incrimination." 107

Similarly, in United States v. Cancilla, ${ }^{108}$ the court held that representation by an attorney who possibly committed similar crimes, which were linked to the client's criminal activity, constituted "a per se violation of the Sixth Amendment right to effective assistance of counsel." The court reasoned that the attorney might not have vigorously defended the client due to the possibility of uncovering evidence that would reveal the attorney's own crime. ${ }^{109}$

Application of the rationale of these two cases to a defendant whose attorney is threatened with prosecution for money laundering leads to the conclusion that the money laundering provisions create a conflict of interest which separates the client's and the attorney's best interests and violates the defendant's right to effective assistance of counsel. ${ }^{110}$ In summary, section 1957 places an attorney who accepts a bona fide representation fee in a direct conflict with his client, thus depriving that client of his sixth amendment right to effective assistance of counsel. 111

2. Chilling of Attorney-Client Communications. A second impediment to a client's right to effective assistance of counsel arises when the attorney-client

would violate the attorney's duty to give independent advice solely for the benefit of his client under the Model Code of Professional Responsibility DR 5-103(A), EC 5-1,2,3,7 (1981)). See also Krieger \& Van Dusen, supra note 71 , at 741 (prosecutor may offer a plea to a count that does not require forfeiture); Note, Against Forfeiture of Attorney's Fees Under RICO, supra note 8, at 142 (attorney may be forced to negotiate rather than risk conviction and forfeiture at trial); Note, Forfeiture of Attormey's Fees, supra note 8, at 1180-81 (attorney may be forced to choose a litigation strategy which would protect his interests rather than choosing a strategy which would keep his client out of jail, but would subject the attorney's fee to forfeiture).

106. 748 F.2d 125, 136 (3d Cir. 1984).

107. Id.

108. 725 F.2d 867,870 (2d Cir. 1984).

109. Id. at 870-71.

110. See supra text accompanying notes 94-97.

111. One may effectively waive his right to conflicted counsel if the waiver is elected intelligently, knowingly, and voluntarily. Johnson v. Zerbst, 304 U.S. 458, 464-65 (1938). The voluntary standard requires that defendants have a meaningful choice between viable alternatives. Sacrificing one right without utilizing another is not a meaningful choice. See United States v. Bernstein, 533 F.2d 775, 787-88 (2d Cir.), cert. denied, 429 U.S. 998 (1976); Note, $A$ Case of Ineffective Assistance, supra note 62, at 633-34.

Threatening prosecution against a defendant's attorney forces the defendant (via the effect of the money laundering provisions) to either waive his rights to unconflicted private counsel or to accept inadequate public representation. See supra note 71 and accompanying text. Thus, the defendant is involuntarily forced into a situation in which he must choose to waive his sixth amendment right to unconflicted counsel in order to obtain adequate representation. 
privilege is threatened. Although the privilege is not recognized as an independent constitutional right, ${ }^{112}$ it is essential to the constitutionally required right to effective assistance of counsel because the privilege encourages clients to make full and frank disclosures. ${ }^{113}$

An attorney threatened with prosecution for accepting bona fide representation fees will be forced to choose between limiting the investigation in order not to discover any information which may be used against him in a subsequent money laundering prosecution, and inquiring fully into the client's case in order to prepare and present competent legal advice. ${ }^{114}$ Further, the client may feel compelled to withhold information from the attorney fearing that the attorney may be forced to disclose the information in his own defense in a subsequent money laundering prosecution. Thus, the money laundering provisions create a situation which chills communication between the attorney and client. Without protection of the client's attorney from the threat of prosecution, a defendant's right to effective assistance of counsel is compromised.

\section{Potential for Prosecutorial Abuse and Manipulation Threatens Justice in the} Adversarial System. To apply the money laundering provisions to attorneys who take bona fide representation fees will tip the scales of justice in favor of the prosecution and result in the denial of the defendant's due process rights. The current money laundering provisions compromise the defendant's right to effective assistance of counsel by creating conflicts of interest and chilling attorney-client communications. ${ }^{115}$ However, potentially the largest and most serious problem is one of prosecutorial manipulation. The money laundering provisions could be improperly used to selectively threaten prosecution or institute grand jury investigations and, hence, force competent defense attorneys to withdraw from a case due to concerns over imprisonment, ethical

112. The attorney-client privilege is a creature of the common law and state legislatures. See, e.g., Clark v. United States, 289 U.S. 1, 13 (1932). In federal courts, Rule 501 controls; it provides that "the privilege of a witness ... shall be governed by the principles of the common law as they may be interpreted by the courts of the United States in light of reason and experience." FED. R. EVID. 501.

113. Upjohn Co. v. United States, 449 U.S. 383, 389 (1981) (effective advocacy depends on the attorney being fully informed); Trammel v. United States, 445 U.S. 40, 51 (1980) (attorney cannot discharge his duties if he is not fully informed); Hunt v. Blackburn, 128 U.S. 464, 470 (1888) (full disclosure is necessary for the administration of justice).

114. This dilemma is compounded by the requirements of the Model Code of Professional RESPONSIBILITY EC 4-1 (1981), which provides that:

A client must feel free to discuss whatever he wishes with his lawyer, and a lawyer must be equally free to obtain information beyond that volunteered by his client. A lawyer should be fully informed of all the facts of the matter he is handling in order for his client to obtain the full advantage of our legal system.

See also Standards for Criminal. Justice 4-3.1, 4-3.2 (2d ed. 1980) (attorney should seek full disclosure of all facts and encourage clients to be candid).

These standards and duties require the attorney to choose the first alternative of seeking full information regardless of the consequences. However, it is hard to imagine a defense attorney who would advocate his client's position when the result would be to subject himself to criminal or civil liability. See supra notes 106-109 and accompanying text.

115. See supra parts III.C.1. and III.C.2. 
violations involving conflicts of interest, and economic pressure. 116 Further, this tactic could be used repeatedly until the prosecution approves or agrees with the defendant's choice of counsel. ${ }^{117}$

The effect of potential prosecutorial manipulation is a denial of due process as the "balance of forces between the accused and his accuser" are skewed.118 Furthermore, threatening prosecution against a defendant's counsel for taking bona fide representation fees undermines the "very premise of our adversar[ial] system of criminal justice" which is "that partisan advocacy on both sides of a case will best promote the ultimate objective that the guilty be convicted and the innocent go free."119

\section{Conclusion}

Constitutional infringement of a defendant's rights is the unfortunate result of the newest tactic in the war on drugs, gambling, and vice. This infringement denies the defendant his sixth amendment rights to counsel, counsel of choice, and effective assistance of counsel. It arises from threatening and subjecting the defendant's attorney, who takes bona fide representation fees, to criminal and civil prosecution. By failing to focus on the roots of the U.S. vice problem, namely public demand, ignorance of users, and profit motivation, Congress has adopted a statute which is unconstitutionally overinclusive since it violates a defendant's due process and sixth amendment rights. If this new federal enforcement tool is to be used at all, courts must ${ }^{120}$ construe the Money Laundering Contol Act narrowly in order to exclude from the Act's provisions attorneys who take bona fide representation fees.

Adam K. Weinstein

116. See supra notes $63-66,78$ and accompanying text.

117. In analyzing the impact of prosecutorial discretion on attorney fee forfeiture cases, the court in United States v. Rogers, 602 F. Supp. 1322, 1350 (D. Colo. 1985), stated: "The government would possess the ultimate tactical advantage of being able to exclude competent defense counsel as it chooses. ... While I presume that most prosecutors act in good faith, I cannot ignore the potential for prosecutorial manipulation. ..." (emphasis added).

118. Wardius v. Oregon, 412 U.S. 470,474 (1973)

119. 602 F. Supp. at 1350 (citing Herring v. New York, 422 U.S. 853, 862 (1975)).

120. See supra note 43. 